\title{
ДО 80-РІЧЧЯ 3 ДНЯ НАРОДЖЕННЯ ОЛЕКСАНДРА МИКОЛАЙОВИЧА ПОЛЮДОВА
}

Народився майбутній вчений 10 жовтня 1931 р. у м. Фергані обласному центрі Узбецької РСР в сім'ї службовця. 1945 р. за сімейними обставинами Олександр з матір'ю переїздить в Україну (с. Гоща Рівненської області). Після завершення середньої школи 1949 р. вступив у Київський інститут цивільного повітряного флоту ім. К. Є. Ворошилова (тепер Національний авіаційний університет), але за станом здоров'я 1950 р. змушений був залишити його. 1950 р. вступив на інженерно-механічний факультет Українського поліграфічного інституту (УПІ) ім. Івана Федорова, який закінчив 1955 р.

Після завершення навчання й до 1960 р. працював асистентом кафедри поліграфічних машин поліграфічного інституту. 1960-1963 рр. навчався в аспірантурі при УПІ ім. Івана Федорова. 1963 р. працював на посаді доцента кафедри, з 1964 р. старший викладач. 1964-1968 і 1970-1974 рр. виконував обов'язки декана механічного факультету УПІ ім. Івана Федорова.

1965 р. у Львівському політехнічному інституті захистив дисертаційну роботу «Исследование истинной динамики исполнительных и уравновешивающих кулачковых механизмов» на здобуття наукового ступеня кандидата технічних наук.

1965 р. обрано на посаду доцента, 1968 р. ВАК затвердив О. М. Полюдова у вченому званні доцента по кафедрі поліграфічних машин. 3 1975-го до 1986 року - проректор з навчальної роботи УПІ ім. Івана Федорова.

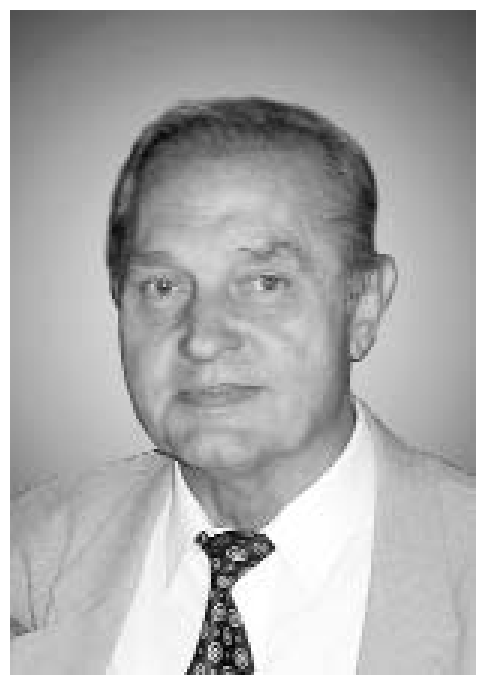

1981 р. у Всесоюзному НДІ комплексних проблем поліграфії захистив дисертаційну роботу «Динамический синтез и исследования устройства программного уравновешивания избыточных загрузок в полиграфических машинах-автоматах» на здобуття наукового ступеня доктора технічних наук.

1982 р. ВАК затвердив О. М. Полюдова у вченому званні професора по кафедрі поліграфічних машин. 1986-2001 рр. - завідувач кафедри поліграфічних машин. 3 2000-го року і до сьогодні - професор цієї ж кафедри Української академії друкарства.

Автор та співавтор 250 наукових та навчально-методичних публікацій, серед яких 15 монографій та навчальних посібників, 70 авторських свідоцтв і патентів на винаходи. Під його керівництвом О. О. Білецький, А. Л. Бойчук, І. К. Георгієвський, В. Ц. Жи- 
децький, А. І. Іванко, В. Т. Іващенко, М. В. Ключковський, С. М. Ключковський, О. Б. Книш, А. Б. Коломієць, Є. І. Котолюз, С. Д. Лазебник, В. О. Лаптєв, А. Нурдінов, Г. Г. Петріашвілі, 3. М. Приставський, І. І. Регей, Н. Я. Кандяк, П. В. Топольницький, В. Г. Яницький виконали та захистили дисертаційні роботи на здобуття наукового ступеня кандидата та доктора технічних наук.

Нагороджений медаллю «За доблестный труд. В ознаменование 100-летия со дня рождения В. И. Ленина», іншими державними нагородами. Присвоєно почесне звання заслуженого працівника вищої школи УРСР. Нагороджено грамотою Верховної Ради України.

Джерело:

Полюдов Олександр Миколайович [Текст] / О. В. Мельников // Українська академія друкарства. 1930-2010. Історикобіографічний довідник ; М-во освіти і науки України. Укр. акад. друкарства. - Львів : Укр. акад. друкарства, 2010. - С. 359360.

Шановні читачі, за цією короткою біографічною довідкою, яку підготував історіограф та бібліограф нашої академії Олександр Валерійович Мельников, колеги та учні, аспіранти та студенти, можуть прослідкувати славний життєвий шлях, головні наукові та педагогічні здобутки відомого українського вченого в галузі поліграфічного машинобудування, заслуженого працівника вищої школи, доктора технічних наук, професора, багатолітнього керівника кафедри поліграфічних машин та інженерно-механічного факульте- ту, проректора з навчальної роботи УПІ ім. Івана Федорова (тепер Українська академія друкарства) Олександра Миколайовича Полюдова.

На жаль, у цій замітці не відображена така важлива сфера науково-педагогічної діяльності Олександра Миколайовича, як участь у роботі спеціалізованих вчених рад із захисту кандидатських та докторських дисертацій при Московському поліграфічному інституті та УП। ім. Івана Федорова, а також у якості члена експертної ради ВАК України. У цій сфері професор Полюдов здійснив величезну роботу по підготовці наукових кадрів вищої кваліфікації, яку добре пам'ятають та цінують ті, чиї роботи він опонував та експертизу яких здійснював.

Особисто ж мені пригадується, як нам студентам-технологам, енергійний, молодий та симпатичний Олександр Миколайович викладав технологію металообробки і як на нього (хай мені пробачить мені ці спогади його дружина Агнеса Олександрівна) заглядались наші однокурсниці. Добре пам'ятаю я й те, як Олександр Миколайович опікувався захистом моєї кандидатської, а потім й докторської дисертацій, як схвально відгукнувся про мою докторську роботу на її захисті в Московському поліграфічному інституті, як відправляв на тривале стажування до інституту поліграфії у Лейпцігу тоді Німецької Демократичної Республіки.

Міркую, що більшість з тих хто зтикався з О. М. Полюдовим у житті згадують про нього, як про надзвичайно ерудованого 
фахівця в галузі поліграфічних машин та технології, як про людину, яка завжди готова прийти на допомогу, вислухати, порадити, і головне - за потреби діяти, як про надзвичайно спокійну, ввічливу, завжди толерантну та елегантну людину.

Особисто мене завжди вражали його величезні знання й те, що він продовжує активно працювати 3 аспірантами та докторантами, приймає найактивнішу участь в житті кафедри, факультету комп'ютерної інженерії академії друкарства, Клубу львівських поліграфістів, до якого його обрали як почесного діяча.

Знаю, що Олександр Миколайович ще багато зробить для нашої академії, що у цьому він знаходить радість і підтримку своїх колег та учнів, своєї чарівної Агнеси Олександрівни та своєї сім'ї.

Вірю і знаю, що під час чествувань ювіляра ми побажаємо цьому прекрасному Науковцю, Педагогу й Людині нових творчих успіхів, здоров'я, щастя, довголіття, бо Він того вартий!

Вдячний учень Едуард Лазаренко, інженер-технолог, доктор технічних наук, професор, заслужений діяч науки і техніки України

\section{ВІТАННЯ 3 ЮВІЛЕЄM ЮРІЯ ОЛЕКСАНДРОВИЧА БАРНИЧА}

Із безлічі професій на Землі, Яких ще будуть вчити,

Одвічна є одна,

І їй наймення - Учитель!

Благословен той день і час, коли на небі спалахнула нова зірка, яка сповістила, що 03.12.1931 року у Львові народився хлопчик, якому батьки нарекли ім'я Юрій. В отчому домі робив він перші кроки, там пройшли перші весни, звідси вийшов на дорогу самостійного життя.

Батьки раділи, що Отець Небесний нагородив сина світлим

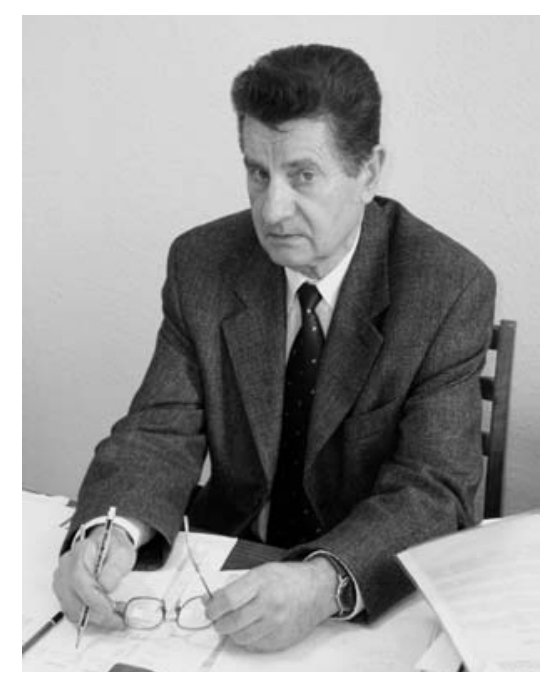

